\title{
5. PROVENANCE OF DROPSTONES IN BAFFIN BAY AND LABRADOR SEA, LEG 105 ${ }^{1}$
}

\author{
J. A. Korstgärd ${ }^{2}$ and O. B. Nielsen ${ }^{2}$
}

\begin{abstract}
Particles greater than about $1 \mathrm{~cm}$ from cores recovered at Sites 645, 646, and 647 and particles from 2 to $10 \mathrm{~mm}$ from selected samples in cores from 0 to 160 meters below seafloor (mbsf) of Site 645 have been analyzed to elucidate their provenance. Results from this investigation reveal that the size of dropstones in Baffin Bay (Site 645) range up to the diameter of the core (i.e., $7.5 \mathrm{~cm}$ and perhaps greater), while dropstones may be up to $3.5 \mathrm{~cm}$ in cores from the Labrador Sea. The total quantity of dropstones in Baffin Bay is 20 times greater than that in the Labrador Sea. We believe this tremendous difference in the amount of dropstones is because calving intensity, especially in Western Greenland, is much higher, and because most icebergs are trapped in Baffin Bay at the narrow and shallow connection to the Labrador Sea through the Davis Strait. Dropstone composition is also very different in the three sites. In cores from Baffin Bay, carbonates (especially dolomites) make up a considerable part of this material, especially in the interval at 160-330 mbsf, while they are absent at Site 646, near the southern tip of Greenland, and only occur sporadically at Site 647, nearer Newfoundland. We believe this difference in composition results from the different provenance. Material from Baffin Bay has a major source on the west coast of Greenland and the adjacent Canadian Islands, where Precambrian carbonates are found north of Baffin Bay. The source of dropstones at Site 646 is probably those glaciers that calve in East Greenland, where no carbonates are present, whereas Site 647 received dropstones from both sources. In colder periods, the sedimentation of dropstones almost stopped in Baffin Bay, probably because icebergs did not melt. The first occurrence of dropstones is most likely marked by the presence of what may be Mesozoic shale clasts at 605 mbsf (about $8 \mathrm{Ma}$ ). Below $330 \mathrm{mbsf}$, these shale clasts are the dominant type of dropstone present.
\end{abstract}

\section{INTRODUCTION}

The Quaternary sediments in Baffin Bay probably originated from Labrador, Baffin, Devon and Ellesmere islands, and from northern and central West Greenland. Transport and sedimentation mechanisms for the sediments include turbidity and contour currents, sedimentation from suspension, meltout from icebergs, and probably an aeolian source. The importance of these mechanisms and their variation through time is unknown; however, a systematic investigation of the size and frequency of particles larger than $2 \mathrm{~mm}$, which undoubtedly are deposited from melting icebergs, might clarify the importance of this particular mechanism. The composition of these particles may indicate their source, and thus the drift paths of icebergs.

The first occurrence of dropstones in the sedimentary record is important for dating the onset of glacial conditions in the area. To compare the situation in Baffin Bay (represented by Site 645) to more open oceanic areas, materials from Sites 646 and 647, in the Labrador Sea (Fig. 1), were included.

For these purposes, particles that were visible on the cut surface of the core and larger than approximately $1 \mathrm{~cm}$ from all cores at all three sites, were sampled individually. Particles larger than $2 \mathrm{~mm}$ were obtained by wet sieving $10-\mathrm{cm}^{3}$ samples. About 130 samples were processed from the upper 160 mbsf in the cores from Baffin Bay. Results of petrographic analyses are included in this study. These results are not included in the figures, as no similar data are available for the two Labrador Sea sites, but results are used to confirm the compositional variations in dropstone lithology from the upper part of the Baffin Bay section. Note that no particles larger than $1 \mathrm{~cm}$ were found in these 130 samples.

\footnotetext{
${ }^{1}$ Srivastava, S. P., Arthur, M., Clement, B., et al., 1989. Proc. ODP, Sci. Results, 105: College Station, TX (Ocean Drilling Program).

${ }^{2}$ Department of Geology, Aarhus University, 8000 Aarhus C, Denmark.
}

\section{METHODS}

Particles larger than about $1 \mathrm{~cm}$ were thoroughly cleaned in water and cut into two pieces when necessary for classification. Dropstones were examined using a hand lens, a $10 \% \mathrm{HCl}$ solution, and a penknife. We estimated the approximate size of the dropstones, with a fraction up to $1 \mathrm{~cm}$ in diameter and then in increments of 1 up to $6 \mathrm{~cm}$, which is near the maximum size of the encountered dropstones (from the size of core diameter).

\section{DROPSTONES}

These dropstones include sedimentary, igneous, and metamorphic rocks. The sedimentary rocks include clastics and carbonates. The clastic rocks are dominated by fine-grained, well-sorted, mainly nonquartzitic sandstones; quartzites and siltstones occur frequently. Of minor inportance are claystones and poorly sorted arkosic and conglomeratic rocks. The carbonates, comprising both limestones and dolomites, are mainly light yellow gray to dark gray rocks, some of which appear brecciated.

The igneous rocks are dominated by quartzdioritic to tonalitic rocks. The main minerals are plagioclase, quartz, and amphibole. Granites sensu stricto and anorthositic rocks are scattered. The only basic rocks observed are basalts, and then only in subordinate amounts.

The metamorphic rocks are completely dominated by biotite gneisse; whose main minerals are quartz, plagioclase, and biotite. More biotite-rich mica schists occur frequently and may occasionally be garnet-bearing. Amphibolites occur only in minor amounts.

The dropstones were first classified as either sedimentary, igneous, or metamorphic. Sedimentary dropstones were further divided into carbonates, nonquartzitic sandstones, quartzites, siltstones, and claystones. Igneous rocks were divided into granitoids and basic rocks (mainly basalts), and metamorphic rocks were divided into gneisses and amphibolites.

Sedimentary dropstones were divided only into carbonates and clastics, and all igneous and metamorphic rocks were grouped together as crystalline because the amount of dropstones of sub- 


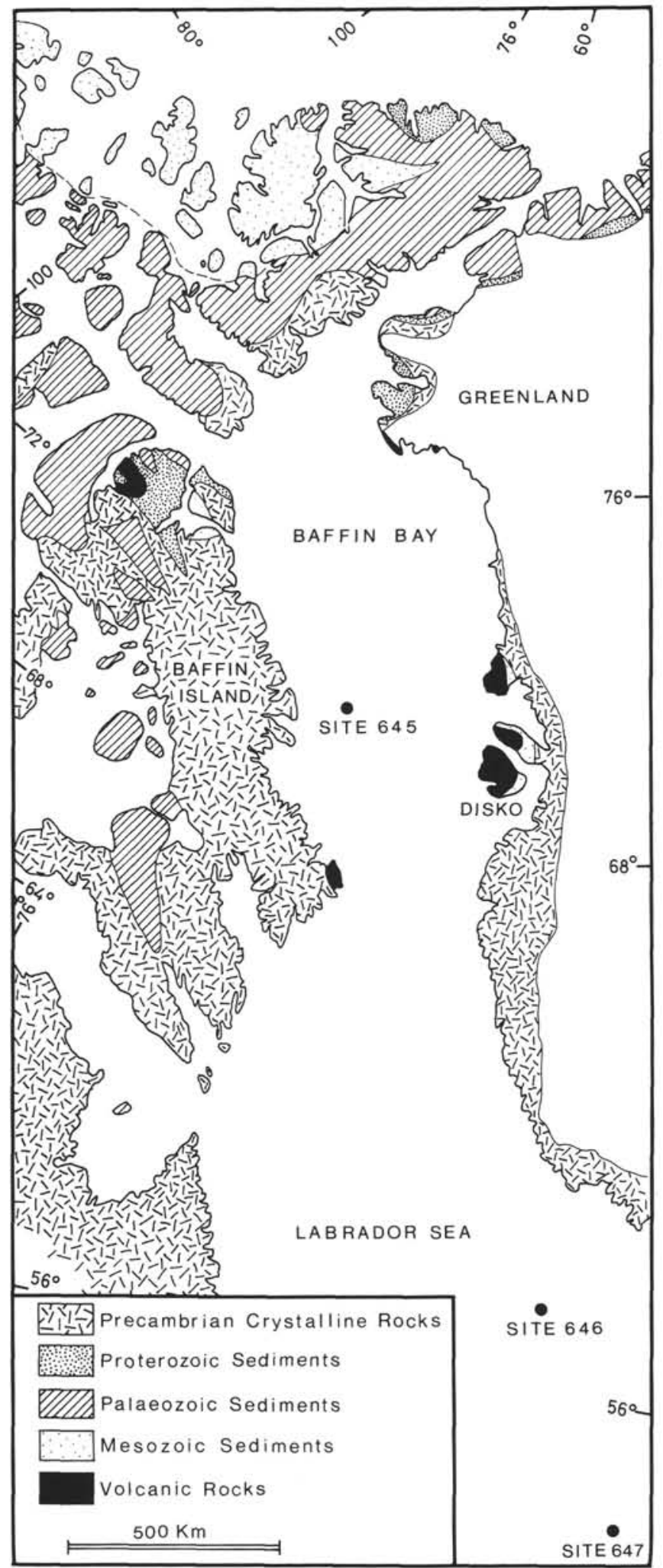

Figure 1. Map showing locations of Sites 645, 646, and 647 and generalized geological features of the surrounding continental areas (after Douglas, 1967, and Escher, 1970). ordinate lithologies was so limited that we could draw no statistically significant conclusions.

Here, the number of dropstones, average size, and maximum size of dropstones within each 10 -m interval was plotted vs. depth. We did this for each category of dropstone.

\section{RESULTS}

\section{Site 645}

\section{Number of Dropstones}

The total number of dropstones in each 10 -m interval is plotted vs. sub-bottom depth in Figure 2. Depicted in the same diagram is the expected number of dropstones if total recovery in all cores were obtained. The frequency of dropstones shows a number of peaks throughout the sequence, i.e, the distribution is cyclic. High frequencies occur in the intervals from 0 to $20 \mathrm{~m}$, 160 to $220 \mathrm{~m}, 250$ to $310 \mathrm{~m}$, and 400 to $420 \mathrm{~m}$, where we usually found more than 10 stones for each $10-\mathrm{m}$ core. The variation in frequency probably represents a true variation in the supply of dropstones because no similar variations were found in the sediment-accumulation rates; thus, this variation most likely is related to climatic fluctuations.

\section{Dropstone Lithology}

Sedimentary rocks are dominant throughout the sequence, especially in the upper and middle parts, where they exceed the number of crystalline rocks by a factor of two or three (Fig. 3).

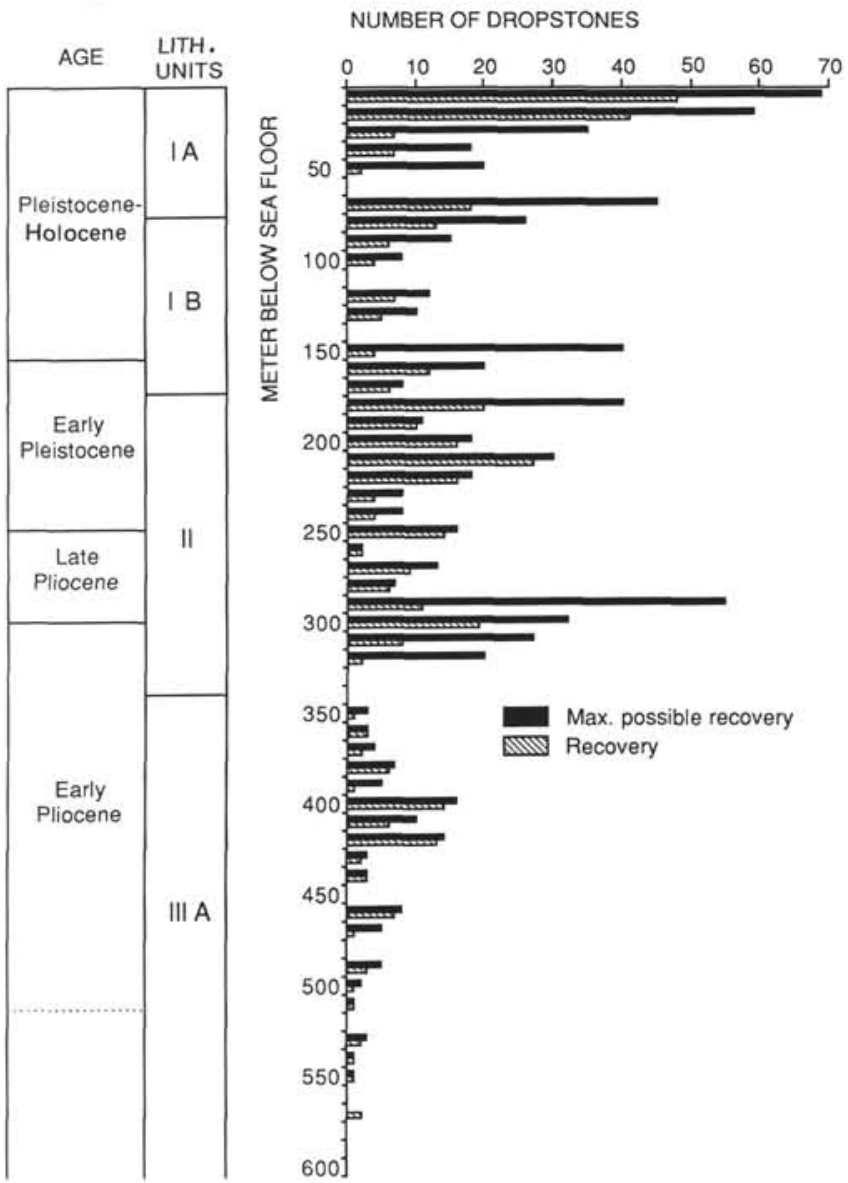

Figure 2. Site 645. Number of dropstones in each core (hatched bars) and expected number of dropstones if total recovery were obtained (solid black bars). 


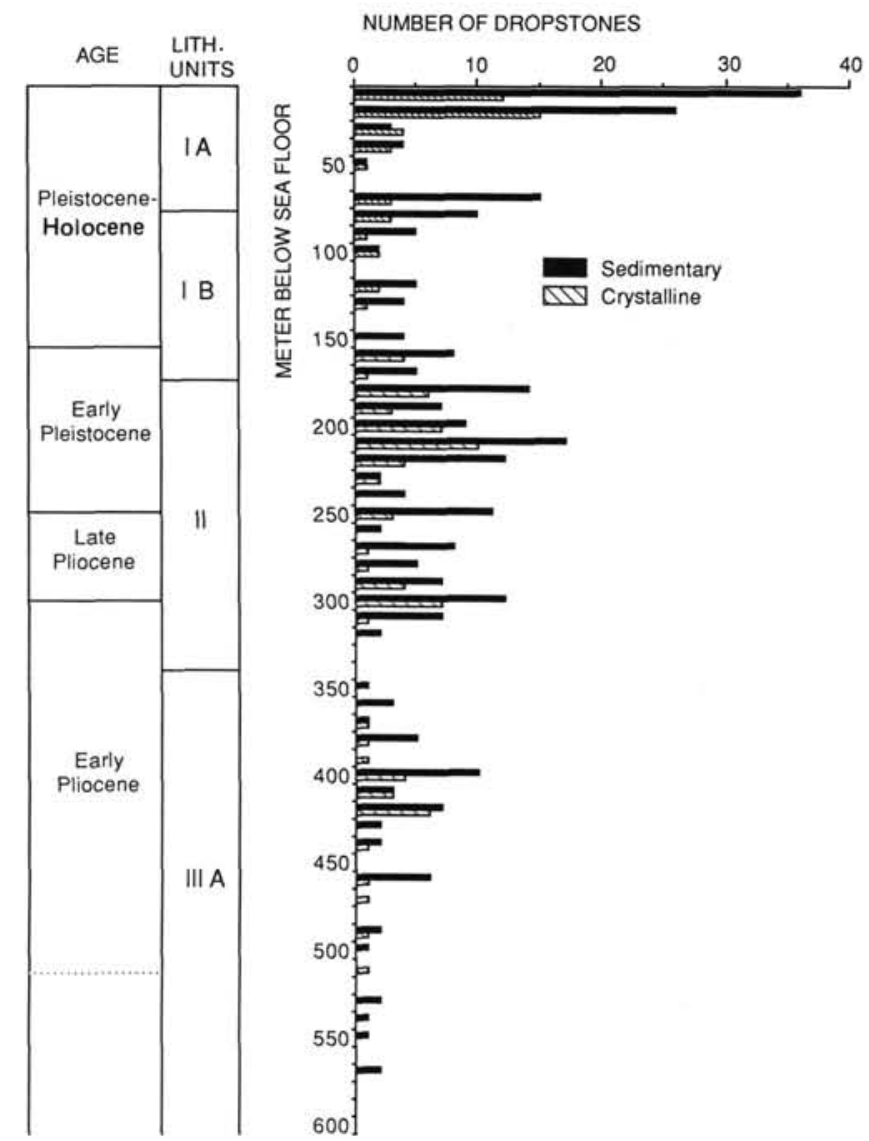

Figure 3. Site 645. Number of sedimentary dropstones (solid black bars) and crystalline dropstones (hatched bars) in each core.

In the upper part of the section (0-100 m), clastic dropstones are more frequent than carbonates (Fig. 4). Below about $150 \mathrm{~m}$ and down to about $320 \mathrm{~m}$, carbonate rocks are more frequent than clastic rocks. Below $320 \mathrm{~m}$, clastics again dominate, and below $460 \mathrm{~m}$, no carbonate dropstones were found.

In the upper two cores, the amount of igneous dropstones is highest and exceeds that of metamorphic dropstones. Below about $150 \mathrm{~m}$ and down to about $300 \mathrm{~m}$, metamorphic dropstones are more frequent than igneous dropstones. Below $300 \mathrm{~m}$, igneous dropstones are scattered (Fig. 5).

\section{Size Distribution of Dropstones}

Below $200 \mathrm{~m}$, the maximum size of all dropstones decreases to less than $2 \mathrm{~cm}$ in the deepest part of the section. The crystalline rocks never exceed $5 \mathrm{~cm}$, and rocks of this size occur only in the middle interval. Sedimentary rocks have their maximum size in the upper part $(0-200 \mathrm{~m})$ of the section. Carbonates have maximum size in the middle part and have a smaller maximum size in the deepest part (Fig. 6). Clastics exhibit their maximum size in the upper part.

The average size of sedimentary dropstones is largest in the upper and middle parts of the section, whereas crystalline dropstones show maximum abundances in the middle and lower parts.

The average size of clastics varies little; there is a tendency toward maximum average size in the upper parts of the section. Carbonates are clearly larger in the upper and especially in the middle parts and show a drastic decrease in the lower part of the section.

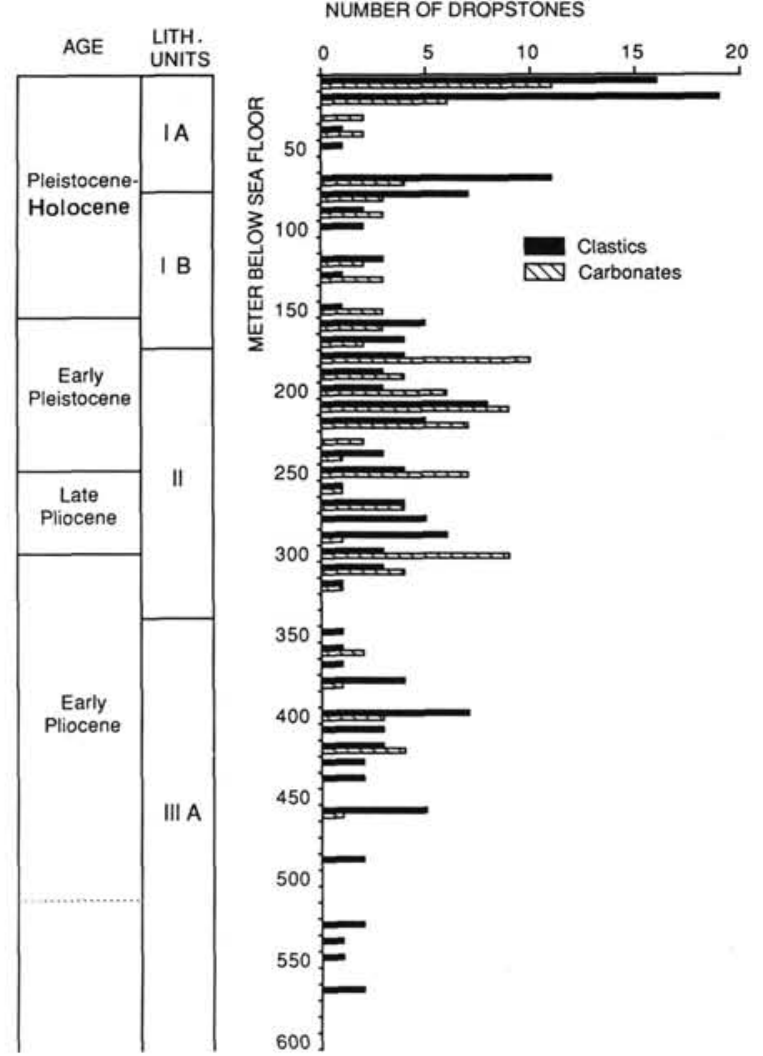

Figure 4. Site 645. Number of clastic dropstones (black bars) and carbonate dropstones (hatched bars) in each core.

\section{First Occurrences of Dropstones}

Below 330 mbsf, shale clasts of probable Mesozoic origin are frequent, carbonates are found to a depth of $460 \mathrm{mbsf}$, and crystalline clasts can be seen down to 510 mbsf. Below this depth, shale clasts are present down to about 605 mbsf (Srivastava, Arthur, et al., 1987).

In facies 2 (Hiscott et al., this volume), no dropstones larger than $1 \mathrm{~cm}$ and only a few larger than $2 \mathrm{~mm}$ were found. In other facies and lithotypes, no distinct differences in composition and amount were observed.

\section{Sites 646 and 647}

Compared with Site 645 , the total number of dropstones and their maximum sizes are much smaller at Site 646 and smaller again at Site 647.

At Site 646 , only one carbonate particle was found; sedimentary dropstones no longer occur below 90 mbsf. Only crystalline dropstones can be seen below this depth, and then in decreasing amounts and sizes downhole. Dropstones first occur at about 195 mbsf.

At Site 647 , dolomitic dropstones dominate and no other sedimentary rocks are present. Below $110 \mathrm{mbsf}$, no dropstones were found.

\section{Sediment Accumulation Rates}

Accumulation rates of dropstones (expressed in $\mathrm{cm}^{3} / 1000 \mathrm{yr}$ ) at the three sites are shown in Figure 7. One can see that accumulation rates within the three sites vary with an order of magnitude, with the largest rates at Site 645 . In addition, within the last 2.5 Ma, total accumulation rates vary widely. At Site 645 , these rates range from 517 to $711 \mathrm{~cm}^{3} / 1000 \mathrm{yr}$; at Site 646 , from 


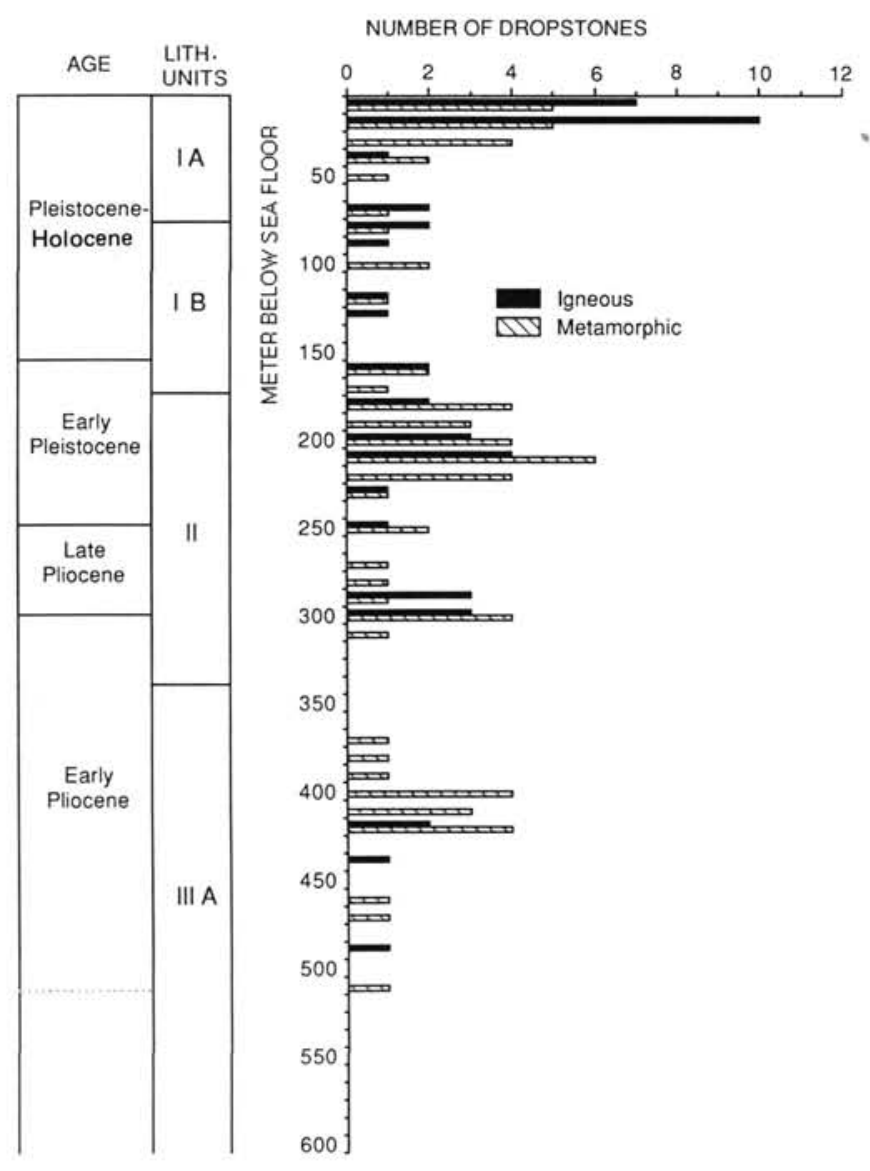

Figure 5. Site 645. Number of igneous dropstones (black bars) and metamorphic dropstones (hatched bars) in each core.

314 to $442 \mathrm{~cm}^{3} / 1000 \mathrm{yr}$; and at Site 647 , from 150 to $216 \mathrm{~cm}^{3} /$ $1000 \mathrm{yr}$.

\section{DISCUSSION}

In the Labrador Sea, at Sites 646 and 647, the first true dropstones occur in sediments having an age of about $2.5 \mathrm{Ma}$ (Arthur et al., 1986a, 1986b; Srivastava, Arthur, et al., 1987). Sediments of this age were found at about 335 mbsf at Site 645 in Baffin Bay, where a major change in matrix lithology is seen. This event probably represents the onset of major ice rafting in the Northern Hemisphere. In Baffin Bay, however, true dropstones having smaller and decreasing abundances downhole were observed, indicating that glacial periods began before $2.5 \mathrm{Ma}$. The scattered shale clasts in the lowermost section may have been transported to Site 645 by a sea ice having an age of up to $8 \mathrm{Ma}$ (Srivastava, Arthur, et al., 1987).

The distinct difference in composition of dropstones in Baffin Bay compared with those in Labrador Sea, especially the abundance of carbonates at Site 645 and the almost total absence of this type of dropstone at Sites 646 and 647, indicates different sources for ice-rafted material in the two areas. The Baffin Bay dropstones originate exclusively from the surrounding continental areas and shelves, but only a few icebergs escaped Baffin Bay through the narrow and shallow Davis Strait. The few icebergs that escaped probably drifted southwestward, just as they do today, along the Labrador coast, and are thus responsible for the scattered occurrence of carbonate dropstones at Site 647. The dominant part of the ice-rafted material at Site 647 , and probably all the ice-rafted material at Site 646 , has a lithologic composition that might originate from both the conti-

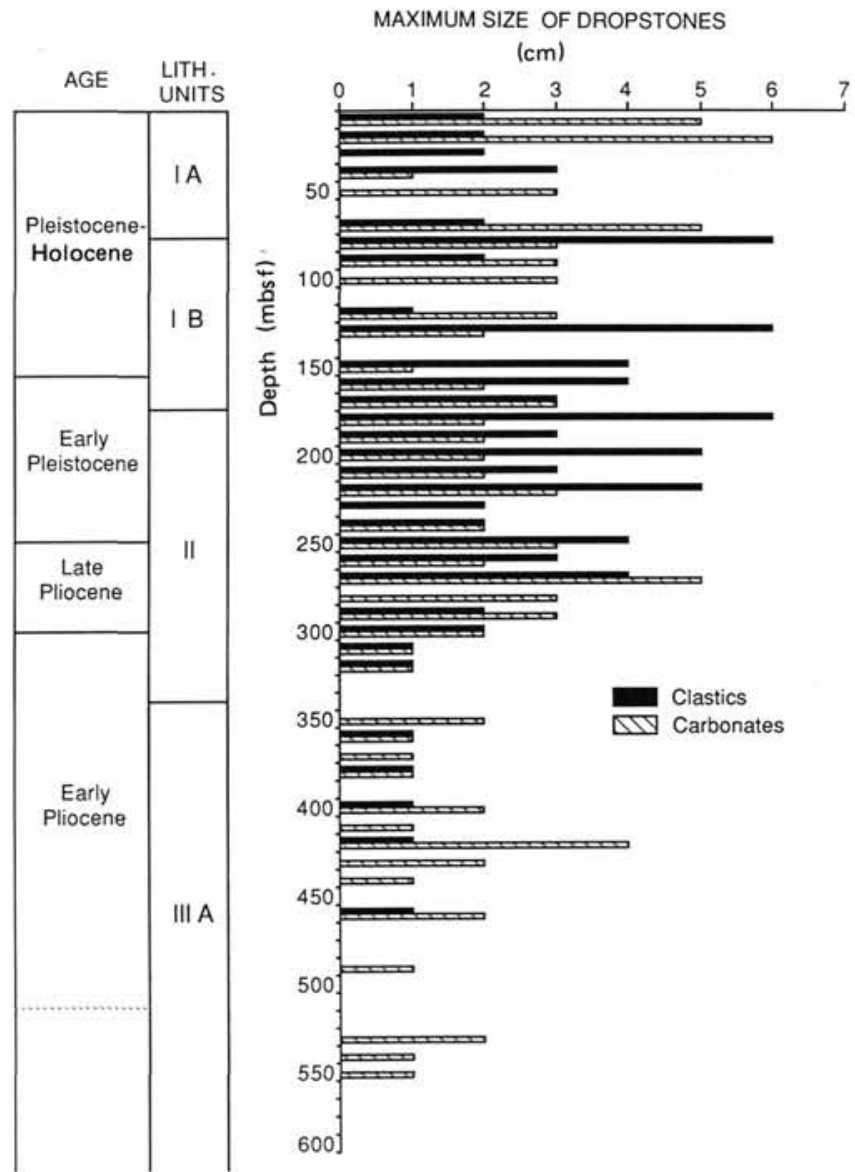

Figure 6. Site 645. Maximum size of sedimentary dropstones in each core. Black bars = clastics; hatched bars = carbonates.

nental areas around Baffin Bay and from eastern and possibly also northern Greenland. As the carbonate dropstones (characteristic for Baffin Bay) are absent or almost absent in the Labrador Sea sites, we surmise that a source located in eastern or northern Greenland is probable. Transport from the source area to the Labrador Sea sites could be explained by iceberg drift paths, which in the last $2.5 \mathrm{Ma}$ generally followed today's iceberg drift-path system.

The distinct differences in the sediment-accumulation rates between the three sites within the last $2.5 \mathrm{Ma}$ are most likely caused by differences in the supply of ice-rafted material. The higher calving intensity for glaciers around Baffin Bay, compared with, for example, the rate around eastern Greenland, explains this phenomenon. Furthermore, the differences in accumulation rates for detrital components are even greater as the amount of biogenic components (mostly calcareous particles of foraminifers and nannofossils) makes up a greater average percentage of the total sedimentary record for the interval in question at Sites 646 and 647 than at Site 645.

At Site 645 , a characteristic change in matrix lithology is present between lithologic Units I and II (Srivastava, Arthur, et al., 1987). In lithologic Unit I (0-168.1 mbsf), detricarbonate particles in the matrix are abundant; however, these particles are rare in lihtologic Unit II (168.1-335 mbsf). In contrast, carbonate dropstones occur more often in lithologic Unit II than in Unit I. The provenance of materials in Unit II, equivalent to Lithotype 1D of Hiscott et al. (this volume), is diffuse, but the presence and dominance of greater carbonate particles indicate that a supply of icebergs from "carbonate terrains" is more abundant than indicated by the composition of the matrix. 

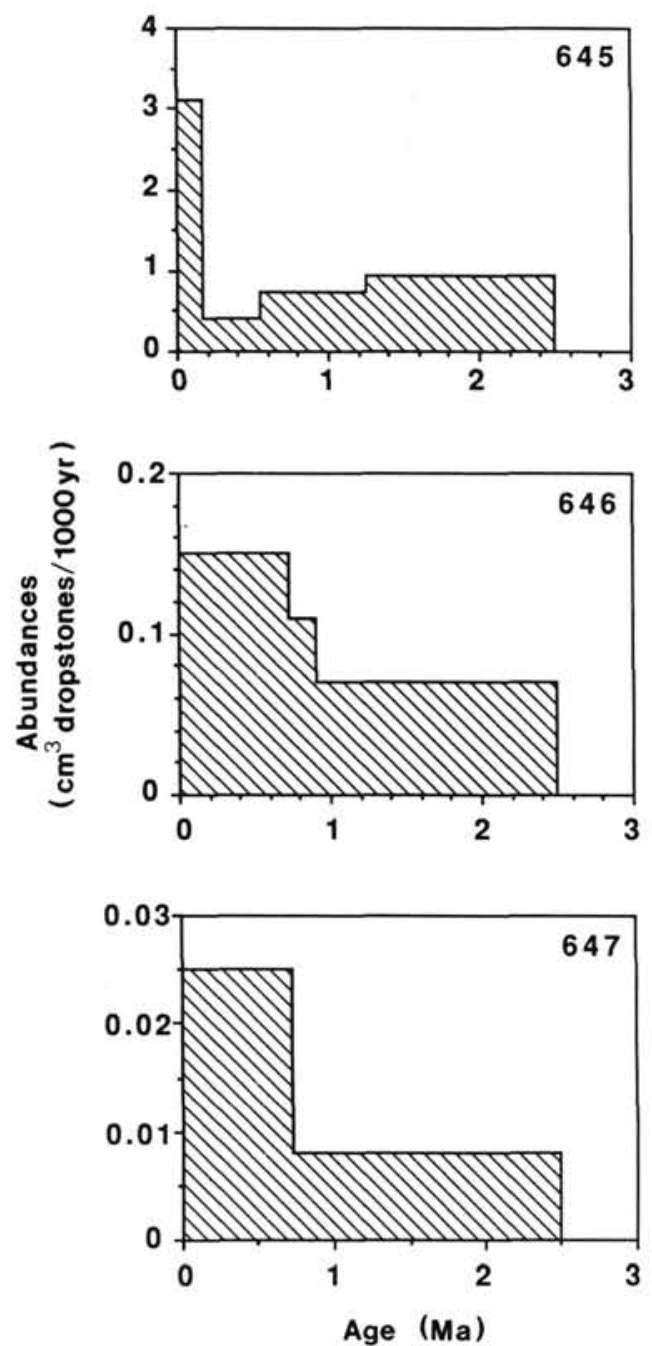

Figure 7. Dropstone accumulation rates in cubic centimeters of dropstones per $1000 \mathrm{yr}$ at Sites 645,646 , and 647 . Note the difference in vertical scale in the three diagrams.

Other transport mechanisms besides meltout from icebergs are more likely for the matrix than for the much more abundant dropstones; thus, the provenance signal for ice-rafted components (given by the dropstones) is probably stronger than the signal given for the different matrix constituents. Thus, the source area for ice-rafted components in the interval from 168.1 to 335 mbsf probably was mainly a carbonate terrain, while the period above and below had source areas for the ice-rafted material that were also located outside the carbonate terrain. The abundance of detricarbonate matrix particles in the interval from the seafloor to $168.1 \mathrm{mbsf}$ may also have been transported to Site 645 by mechanisms other than ice rafting. At Site 645 , the stratigraphic fluctuation in the number of dropstones indicates similar trends for all the major compositional types of dropstones (Figs. 3 through 5) and, consequently, also for the total number (Fig. 2). Generally, but less pronounced, the stratigraphic variation in the maximum size of dropstones has the same trend. Thus, this large-scale variation, which overprints the provenance-related variation in the relationship between the different dropstone compositions, probably reflects a major variation in the total supply of ice-rafted material, which was probably caused by major climatic fluctuations.

\section{CONCLUSIONS}

Results of this study largely confirm the preliminary assessments of the Leg 105 Shipboard Scientific Party and are as follows:

1. The onset of major ice rafting in Baffin Bay and the Labrador Sea has an age of about $2.5 \mathrm{Ma}$.

2. In Baffin Bay, sporadic ice rafting can be dated back to about $8 \mathrm{Ma}$.

3. The amount of ice-rafted material deposited in Baffin Bay is considerably greater than that deposited in Labrador Sea.

4. The source for this ice-rafted material in Baffin Bay is the surrounding land areas, while in the Labrador Sea, the source is most likely eastern and/or northern Greenland. Only a small amount of these icebergs ever escaped from Baffin Bay.

5. The observed cyclicity in amount and composition of dropstones in Baffin Bay probably reflects climatic fluctuations and variations in the importance of different source areas, but the material is too limited to interpret in more detail.

\section{ACKNOWLEDGMENTS}

Gerhard Bohrmann kindly collected dropstones larger than $1 \mathrm{~cm}$ at the repository. Financial support was provided by Danish Natural Science Research Council Grant J 81-5289.

\section{REFERENCES}

Arthur, M., Srivastava, S., Aksu, A., Baldauf, J., Bohrman, G., Busch, W., Cederberg, T., Clement, B., Cremer, M., Dadey, K., de Vernal, A., Firth, J., Hall, F., Head, M., Hiscott, R., Jarrard, R., Kaminsky, M., Lazarus, D., Monjanel, A-L., Nielsen, O.B., Stein, R., Thiebaulte, F., Zachos, J., and Zimmerman, H., 1986a. Ocean Drilling Program: high-latitude paleoceanography. Nature, 320(6057):17-18.

Arthur, M., Srivastava, S., Aksu, A., Baldauf, J., Bohrman, G., Busch, W., Cederberg, T., Clement, B., Cremer, M., Dadey, K., de Vernal, A., Firth, J., Hall, F., Head, M., Hiscott, R., Jarrard, R., Kaminsky, M., Lazarus, D., Monjanel, A-L., Nielsen, O.B., Stein, R., Thiebaulto, F., Zachos, J., and Zimmerman, H., 1986b. End of spreading and glacial onset dated. Geotimes, :11-14.

Douglas, R.J.W., 1967. Geological Map of Canada, 1:5 mill., Map 1250A: Ottawa (Geol. Survey of Canada).

Escher, A., 1970. Tectonic/Geological Map of Greenland, 1:2.5 mill.: Ottawa (Geol. Survey of Greenland).

Srivastava, S. P., Arthur, M., et al., 1987. Proc. ODP, Init. Repts., 105: College Station, TX (Ocean Drilling Program). 